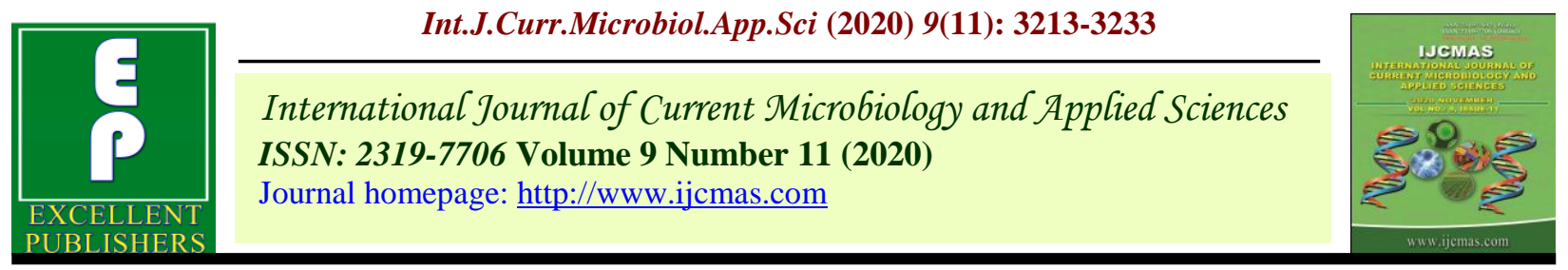

\title{
Influence of Irrigation Management Practices and Different Establishment Methods on Nutrient Use Efficiency of Rice
}

\author{
T. Theerthana ${ }^{1^{*}}$, P. S. Fathima ${ }^{2}$, G. R. Denesh ${ }^{3}$, S. S. Prakash ${ }^{4}$ and N. N. Asha ${ }^{5}$ \\ ${ }^{1}$ University of Agricultural Sciences, GKVK, Bengaluru, India \\ ${ }^{2}$ Department of Agronomy, COA, V.C. Farm, Mandya, UAS, Bengaluru, India \\ ${ }^{3}$ AICRP Rice, ZARS, V.C. Farm, Mandya, UAS, Bengaluru, India \\ ${ }^{4}$ Department of Soil Science and Agricultural Chemistry, COA, V.C. Farm, Mandya, UAS, \\ Bengaluru, India \\ ${ }^{5}$ Department of Agricultural Microbiology, COA, V.C. Farm, Mandya, UAS, Bengaluru India \\ *Corresponding author
}

\section{A B S T R A C T}

\begin{tabular}{l} 
Ke y w or d s \\
Irrigation \\
Management \\
Practices, Rice \\
\hline Article Info \\
\hline $\begin{array}{l}\text { Accepted: } \\
22 \text { October } 2020 \\
\text { Available Online: } \\
10 \text { November } 2020\end{array}$ \\
\hline
\end{tabular}

A field experiment was conducted at Zonal Agricultural Research Station, V. C. Farm, Mandya, to study the effect of irrigation management practices and rice establishment methods on growth and yield of rice (Oryza sativa L.) during Kharif 2018. The experiment was laid out in split plot design with three main plot irrigation methods and five sub plot rice establishment methods. The combination of 15 treatments was replicated thrice. The results revealed significantly higher leaf area $\left(920.61 \mathrm{~cm}^{2}\right.$ hill $\left.{ }^{-1}\right)$, dry matter production (70.82 $\left.\mathrm{g} \mathrm{hill}^{-1}\right)$ at harvest, net returns $\left(42,495 \mathrm{Rs}^{\left.-\mathrm{ha}^{-1}\right)}\right.$ and $\mathrm{B}: \mathrm{C}$ ratio (2.00) in alternate wetting and drying up to PI followed by flooding $3 \pm 2 \mathrm{~cm}$ after PI method of irrigation. While among establishment methods, manual transplanting recorded significantly higher grain yield $\left(5253 \mathrm{~kg} \mathrm{ha}^{-1}\right)$. Interaction between alternate wetting and drying up to PI followed by flooding $3 \pm 2 \mathrm{~cm}$ after PI and mechanical transplanting recorded higher gross returns (99,377 Rs. ha $\left.{ }^{-1}\right)$, net returns $\left(55,112 \mathrm{Rs} \mathrm{ha}^{-1}\right)$ and $\mathrm{B}: \mathrm{C}$ ratio (2.25).

\section{Introduction}

Rice which belongs to Poaceae family is the second important crop after wheat in the world. It is the staple food in Asia, Latin America, parts of Africa and the Middle East. Half of the world's population subsists wholly or partially on rice (Yadav et al., 2009). In India, rice cultivation area extends from $8^{\circ} \mathrm{S}$ to $34^{\circ} \mathrm{S}$ latitude i.e. extending almost throughout the country such as areas lying below sea level (Kerala) and up to an altitude of $2000 \mathrm{~m}$ mean sea level (Kashmir) (Somasundaram et al., 2000). The area occupied by rice crop is around 43.99 million ha in India with a production and productivity of 109.69 million tonnes and $2494 \mathrm{~kg} \mathrm{ha}^{-1}$, respectively (Anon., 2017). Rice is the staple food for more than $2 / 3^{\text {rd }}$ of population in India. As the crop plays a fundamental role in our national food security and is a means of livelihood for millions of rural families, the slogan "Rice for life" is most appropriate. 
In terms of area cultivated, rice ranks second. Forty percent of world population uses rice as a prime source of calories. In terms of calorific value, rice crop occupies first place than any other cereal crops. $74.8 \mathrm{~g}$ carbohydrates, $2.6 \mathrm{~g}$ fat and $8.4 \mathrm{~g}$ protein in the form of oryzenin is present in $100 \mathrm{~g}$ of rice grain. The remaining are other minerals, amino acids and fibre content. Thus $100 \mathrm{~g}$ of rice can supply $477 \mathrm{kcal}$ of energy.

It is estimated that, by 2025 the rice demand will be 140 million tonnes in India (Hugar et al., 2009). In order to attain this target, the productivity of rice has to be ushered to the level of 3.3 tonnes ha $^{-1}$ from present level of 2.2 tonnes ha $^{-1}$ (Anjani et al., 2014). Increase in production has undoubtedly to come from increased productivity under shrinking resources.

The increasing global demand for water in many sectors, including agriculture and intensifying water dearth has become a universal concern. In the next two decades, the share of water devoted to irrigation is expected to decline by 10 to $15 \%$ (Dhawan, 2017). Increasing water paucity is becoming real threat to rice cultivation. Around 13 million ha of Asia's wet-season rice and 2 million ha of its dry-season rice will encounter "physical water scarcity" by 2025 (Bouman and Tuong, 2001). Hence efficient water use technology which also conserves soil health, sustainability as well as economical stability is the only approach to save water for escalating irrigated agriculture (Subramaniam et al., 2013). To accomplish this, diverse approaches have to be adopted and among them, enhancing water productivity or water use efficiency (WUE) is of foremost importance. Survey of literature shows that average WUE of major crops in India varies from 0.28 to $1.60 \mathrm{~kg} \mathrm{~m}^{-3}$ with ample differences among crop species.
Water has been taken for granted in irrigated rice production for centuries, but the looming water crisis may change the method of rice production in the future. Water saving technologies that were examined in the early 1970's such as maintaining soil under saturated condition and alternate wetting and drying are receiving renovated attention by researchers. One operation that has been revealed to trim down water use in rice systems is an irrigation management practice referred to as Alternate Wetting and Drying (AWD) (Lampayan et al., 2015). AWD has been reported to lessen water inputs by $23 \%$ (Bouman and Tuong, 2001) compared to continuously flooded rice systems. As compared with conventional methods, rice grown on saturated soil culture with raised beds reduced the quantity of water use by approximately 32 per cent (Borell et al., 1997).

One of the cultural practices which affect the rice crop through its effect on growth and development is method of establishment (Gopi et al., 2006). Due to non availability of irrigation water, loss of applied nutrients and dearth of labour during peak periods, amplified labour wages make transplanting and manual weeding costly. Thus the area under transplanted rice in world is waning in recent years. Hence, there is call for exploring alternate crop establishment methods to augment the productivity of rice (Farooq et al., 2011). This can be accomplished by adopting diverse establishment techniques in rice such as direct seeded rice, broadcasting, mechanical transplanting, drum seeded rice etc. Mechanical transplanting or direct seeded rice enables timely planting/seeding and better crop stand (Malik et al., 2019). Direct seeded rice can lessen the labour requirement by as much as 50 per cent (Singh et al., 2006).

Challenge is to develop advanced technologies and production systems that 
allow rice production to be sustained or improved in the face of waning water availability. With the intention to find out the efficient water and nutrient saving technology and method of establishment, a field experiment was undertaken.

\section{Materials and Methods}

The experiment was conducted at Zonal Agricultural Research Station, V. C. Farm, Mandya, University of Agricultural Sciences, Bengaluru under Cauvery Command Area of Karnataka to study the effect of irrigation management practices and rice establishment methods on growth and yield of rice during Kharif 2018. The experiment was laid out in a split plot design comprised of three main plot irrigation treatments, viz. Continuous flooding, Maintenance of saturation up to panicle initiation (PI) and flooding after PI and Alternate wetting and drying (AWD) up to panicle initiation (PI) and flooding after PI and five sub plot rice establishment treatments, viz. Drum seeded rice, Broadcasting of sprouted rice, Semi-dry rice, Mechanical transplanting and Manual transplanting. The combination of 15 treatments replicated thrice and medium duration paddy variety 'MTU 1001' was used for the field experiment.

Soil of the experimental site was sandy loam containing organic carbon $(0.67 \%)$, available nitrogen $(270.04 \mathrm{~kg} / \mathrm{ha})$, phosphorus (87.03 $\mathrm{kg} / \mathrm{ha})$ and potassium (287.14 kg/ha). The experiment comprised of three different irrigation methods. Irrigation was applied and quantified through PVC pipes connected to water meter. Fifteen days prior to sowing, $10 \mathrm{t}$ ha $^{-1}$ FYM was applied to the experimental plots and it was incorporated into the soil. Recommended dose of $100 \mathrm{~kg} \mathrm{~N} \mathrm{ha}^{-1}, 50 \mathrm{~kg}$ $\mathrm{P}_{2} \mathrm{O}_{5} \mathrm{ha}^{-1}, 50 \mathrm{~kg} \mathrm{~K} \mathrm{O}^{-1}, 20 \mathrm{~kg} \mathrm{ZnSO}_{4} \mathrm{ha}^{-1}$ fertilizers were applied through urea, single super phosphate (SSP), muriate of potash
(MOP) and zinc sulphate $\left(\mathrm{ZnSO}_{4}\right)$, respectively. $50 \%$ of $\mathrm{N}$, full amount of $\mathrm{P}, \mathrm{K}$ and $\mathrm{ZnSO}_{4}$ were applied as basal dose and the remaining quantity of $\mathrm{N}$ was applied in two splits and was top dressed at 35 and 60 DAS. However, $0.4 \% \mathrm{FeSO}_{4}$ and humic acid was sprayed at 45 and 65 DAS to overcome the deficiency of iron. Irrigation was provided at daily basis for Continuous flooding method, once in 2-3 days for Maintenance of saturation up to panicle initiation (PI) and flooding after PI and once in 5-6 days for AWD depending on the soil condition. Necessary aftercare operations were followed as per the recommendations. No major pest and disease incidences were noticed during crop growth. Observations on growth parameters were recorded at regular intervals - 30, 60, 90 days after sowing and at harvest. Observations recorded during different phenological phases of rice crop were analyzed statistically to find out the result and to draw a conclusion of the experiment conducted. Fisher's method of analysis of variance (ANOVA) was used in the analysis as given by Gomez and Gomez (1984). Significance between the treatments was tested by "F" test. Whereas, difference between the treatments mean were tested by critical difference (CD) at 5\% level of significance.

\section{Results and Discussion}

\section{Leaf area}

The data on leaf area as influenced by irrigation and rice establishment methods recorded at 30, 60, $90 \mathrm{DAS}$ and at harvest are presented below in table 1 .

At 30 and 60 DAS, effect of irrigation methods was non significant. While at 90 DAS and at harvest, alternate wetting and drying up to PI followed by flooding after PI recorded higher leaf area (1228.46 and 920.61 
$\mathrm{cm}^{2}$ hill $^{-1}$, respectively) than other methods. Similar observations were also made by Nguyen et al., (2009). It might be due to more plant dry matter which resulted in greater leaf area at tillering and heading stages as recorded in this study. Bouman et al., (2005) have also observed that the reduction in leaf area might be due to reduced turgor pressure under moisture stress conditions which affected the leaf cell expansion. Among establishment methods, at 30 DAS, semi dry rice recorded significantly higher leaf area $\left(165.62 \mathrm{~cm}^{2}\right.$ hill $\left.^{-1}\right)$ over rest of the methods (13.91 to $102.83 \mathrm{~cm}^{2}$ hill $^{-1}$ ). At 60, 90DAS and at harvest, mechanical transplanting recorded significantly higher leaf area (721.85, 1528.53 and1020.46 $\mathrm{cm}^{2}$ hill $^{-1}$, respectively) was superior over rest of the establishment methods. Among interactions, continuous flooding with semi dry rice $\left(191.71 \mathrm{~cm}^{2}\right.$ hill $\left.^{-1}\right)$ at $30 \mathrm{DAS}$, continuous flooding with mechanical transplanting $\left(854.08 \mathrm{~cm}^{2} \mathrm{hill}^{-1}\right)$ at $60 \mathrm{DAS}$, alternate wetting and drying up to PI followed by flooding after PI with mechanical transplanting (1640.11 and $1145.52 \mathrm{~cm}^{2}$ hill $^{-1}$, respectively) at 90 DAS and at harvest, respectively recorded significantly higher leaf area than rest of the interactions.

\section{Dry matter production (g hill $\left.{ }^{-1}\right)$}

The data on dry matter production as influenced by irrigation and establishment methods of rice are presented in table 2 .

At 30 and 60 DAS, continuous flooding recorded higher dry matter production (1.82 and $12.62 \mathrm{~g} \mathrm{hill}^{-1}$, respectively) and was on par with other methods (1.58 to $1.60 \mathrm{~g}$ and 11.35 to $12.43 \mathrm{~g}$ hill $^{-1}$, respectively). However, at 90 DAS and at harvest, alternate wetting and drying up to PI followed by flooding after PI method of irrigation recorded significantly higher dry matter (38.39 and 70.82 $\mathrm{g} \mathrm{hill}^{-1}$, respectively) as compared to rest of the methods (33.10 to $35.42 \mathrm{~g} \mathrm{hill}^{-1}$ and 63.94 to $64.36 \mathrm{~g} \mathrm{hill}^{-1}$, respectively). The increased dry matter production in alternate wetting and drying up to PI followed by flooding after PI might be due to effective utilization of available resources which was favored by aeration of soil in intermittent wetting and drying. These findings were in accordance with Christine et al., (2007). Semi dry rice recorded significantly higher dry matter (3.19 $\left.\mathrm{g} \mathrm{hill}^{-1}\right)$ over rest of the methods $\left(0.27\right.$ to $\left.1.98 \mathrm{~g} \mathrm{hill}^{-1}\right)$ at 30 DAS. However, at 60, 90 DAS and at harvest, mechanical transplanting among establishment methods recorded significantly higher dry matter $(15.04,47.77$ and $78.50 \mathrm{~g}$ hill $^{-1}$, respectively) over rest of the methods (10.11 to $13.06 \mathrm{~g} \mathrm{hill}^{-1}, 28.12$ to $35.85 \mathrm{~g} \mathrm{hill}^{-1}$ and 57.35 to $67.77 \mathrm{~g} \mathrm{hill}^{-1}$, respectively). Similar trend of total dry matter production was observed at 60, 90 DAS and at harvest due to optimum nutrient supply and production of more number of leaves and leaf area which helped in absorption of more solar radiation hence more photosynthesis and more above ground biomass. These results are also in line with findings of Yadav et al., (2010). Interaction between alternate wetting and drying up to PI followed by flooding after PI and mechanical transplanting recorded higher dry matter at 30,60, 90 DAS and at harvest $\left(3.69,17.79,51.25\right.$ and $88.12 \mathrm{~g} \mathrm{hill}^{-1}$, respectively) and was significantly superior over rest of the methods ( 0.24 to $2.73,8.44$ to $14.79,22.23$ to 46.17 and 46.62 to $76.05 \mathrm{~g}$ hill $^{-1}$ respectively).

\section{Grain yield (kg ha-1)}

Data presented in Table 2 on grain yield varied significantly due to establishment methods and interaction between irrigation and establishment methods. No significant difference in grain yield was observed among irrigation methods. However, continuous flooding recorded higher grain yield $(4916 \mathrm{~kg}$ 
$\mathrm{ha}^{-1}$ ) than alternate wetting and drying up to PI followed by flooding after PI (4849 $\mathrm{kg}$ ha ${ }^{1}$ ) and maintenance of saturation up to PI followed by flooding after PI (4828 $\left.\mathrm{kg} \mathrm{ha}^{-1}\right)$. Higher grain yield recorded by manual transplanting (5253 $\left.\mathrm{kg} \mathrm{ha}^{-1}\right)$ was statistically on par with mechanical transplanting and semi dry rice (5171 and $4953 \mathrm{~kg} \mathrm{ha}^{-1}$, respectively) and was significantly superior over rest of the establishment methods (4197 to $4749 \mathrm{~kg} \mathrm{ha}^{-1}$ ). Interaction between alternate wetting and drying up to PI followed by flooding after PI and manual transplanting recorded higher grain yield (5745 $\left.\mathrm{kg} \mathrm{ha}^{-1}\right)$ and was statistically similar with interaction of alternate wetting and drying up to PI followed by flooding after PI with mechanical transplanting (5613 kg ha ${ }^{-1}$ ), maintenance of saturation up to PI followed by flooding after PI with manual transplanting (5202 $\left.\mathrm{kg} \mathrm{ha}^{-1}\right)$, continuous flooding with semi dry rice (5189 $\mathrm{kg} \mathrm{ha}^{-1}$ ) and maintenance of saturation up to PI followed by flooding after PI with drum seeded rice $\left(5137 \mathrm{~kg} \mathrm{ha}^{-1}\right)$. However, former treatment was significantly superior over rest of the interactions (4093 to $5104 \mathrm{~kg} \mathrm{ha}^{-1}$ ). It might be due to planting of seedlings before third phyllochron, leading to quick crop establishment and longer tillering period which resulted in higher yield attributes and hence yield in case of transplanted rice. However, increase in grain yield in semi dry and drum seeded rice may be attributed to the early establishment, growth and development of crop along with irrigation methods. These results are in confirmation with the findings of Shantappa (2014).

\section{Nutrient status of soil after harvest of crop}

\section{Nutrients uptake by rice $\left(\mathrm{kg} \mathrm{ha}^{-1}\right)$}

\section{Nitrogen uptake by rice grain $\left(\mathrm{kg} \mathrm{ha}^{-1}\right)$}

Nitrogen uptake by rice grain varied significantly with establishment methods and interaction are presented in Table 3. Among irrigation methods, alternate wetting and drying up to PI followed by flooding after PI recorded higher nitrogen uptake by grain (61.52 $\mathrm{kg} \mathrm{ha}^{-1}$ ) which was on par with continuous flooding $\left(61.51 \mathrm{~kg} \mathrm{ha}^{-1}\right)$ and maintenance of saturation up to PI followed by flooding after PI $\left(60.88 \mathrm{~kg} \mathrm{ha}^{-1}\right)$. Higher available nitrogen content in alternate wetting and drying up to PI followed by flooding after PI might be due to effective mineral uptake by roots with larger surface area (Taiz and Zeiger, 2006). Among establishment methods, manual transplanting recorded significantly higher nitrogen uptake by grain (66.49 $\left.\mathrm{kg} \mathrm{ha}^{-1}\right)$ as compared to rest of the methods (54.08 to $63.74 \mathrm{~kg} \mathrm{ha}^{-1}$ ). Lower nitrogen uptake by grain $\left(54.08 \mathrm{~kg} \mathrm{ha}^{-1}\right)$ was recorded by broadcasting of sprouted rice. This may be due to the water stress conditions created by the competition from more plants per unit area which might have made the roots unable to take up nutrients from the soil due to slow ion diffusion and water movement rates as well as lack of root activity (Dubey and Pessarakli, 2001). Alternate wetting and drying up to PI followed by flooding after PI with manual transplanting recorded significantly higher nitrogen uptake by grain $\left(73.25 \mathrm{~kg} \mathrm{ha}^{-1}\right)$ over rest of the interactions (52.01 to $68.13 \mathrm{~kg} \mathrm{ha}^{-1}$ ). The root growth and activity was found better in case of seedlings transplanted with alternate wetting and drying method of irrigation due to the prolific growth of root which helped plants to absorb more nitrogen and accumulate in grains from comparatively deeper layers. Similar results were recorded by Dass and Chandra, (2012).

\section{Nitrogen uptake by rice straw $\left(\mathrm{kg} \mathrm{ha}^{-1}\right)$}

Alternate wetting and drying up to PI followed by flooding after PI recorded higher nitrogen uptake by straw $\left(58.64 \mathrm{~kg} \mathrm{ha}^{-1}\right)$ and was on par with rest of the irrigation methods (56.85 to $\left.57.14 \mathrm{~kg} \mathrm{ha}^{-1}\right)$. Mechanical 
transplanting recorded significantly higher nitrogen uptake by straw $\left(61.86 \mathrm{~kg} \mathrm{ha}^{-1}\right)$ as compared to rest of the methods (54.91 to $57.53 \mathrm{~kg} \mathrm{ha}^{-1}$ ). Lower nitrogen uptake by straw $\left(54.91 \mathrm{~kg} \mathrm{ha}^{-1}\right)$ was recorded by broadcasting of sprouted rice. Nutrient uptake is a function of soil physical, chemical and biological properties, plant population, quantity of dry matter accumulated by crop and amount of fertilizer applied. Nitrogen uptake is a product of above ground biomass and nitrogen content (Taiz and Zeiger, 2006), which has enhanced the nitrogen uptake significantly in rice by mechanical transplanting method. Among interactions, alternate wetting and drying up to PI followed by flooding after PI with mechanical transplanting recorded significantly higher nitrogen uptake by straw $\left(64.20 \mathrm{~kg} \mathrm{ha}^{-1}\right)$ as compared to rest of the interactions (52.99 to $\left.61.92 \mathrm{~kg} \mathrm{ha}^{-1}\right)$.

\section{Total nitrogen uptake $\left(\mathrm{Kg} \mathrm{ha}^{-1}\right)$}

The total nitrogen uptake in different irrigation methods was non significant. However, alternate wetting and drying up to PI followed by flooding after PI recorded higher total nitrogen uptake at harvest (120.06 $\mathrm{kg} \mathrm{ha}^{-1}$ ) compared with rest of the methods (118.02 to $118.36 \mathrm{~kg} \mathrm{ha}{ }^{-1}$. Among establishment methods, mechanical transplanting recorded significantly higher total nitrogen uptake $\left(125.60 \mathrm{~kg} \mathrm{ha}^{-1}\right)$ followed by manual transplanting $(123.79 \mathrm{~kg}$ $\left.\mathrm{ha}^{-1}\right)$. Lower total nitrogen uptake $(108.99 \mathrm{~kg}$ $\mathrm{ha}^{-1}$ ) was recorded in broadcasting of sprouted rice. This may be due to transplanting of younger seedlings in which the root injury is minimum and presence of more active roots, which resulted in rapid and stable establishment by utilizing more nutrients and moisture for longer period. The results are in conformity with Satyanarayana and Babu (2004). Interaction between alternate wetting and drying up to PI followed by flooding after
PI and manual transplanting recorded significantly higher total nitrogen uptake (134.04 $\mathrm{kg} \mathrm{ha}^{-1}$ ) which was closely followed by alternate wetting and drying up to PI followed by flooding after PI with mechanical transplanting (132.33 $\mathrm{kg} \mathrm{ha}^{-1}$ ) compared to rest of the interactions (109.08 to $125.43 \mathrm{~kg}$ $\left.\mathrm{ha}^{-1}\right)$.

\section{Phosphorus uptake by rice grain $\left(\mathrm{kg} \mathrm{ha}^{-1}\right)$}

Data on phosphorus uptake by rice grain at harvest as influenced by irrigation and establishment methods are presented in Table 4. Phosphorus uptake by rice grain was non significant among irrigation methods. However, continuous flooding recorded higher phosphorus uptake by grain at harvest $\left(11.33 \mathrm{~kg} \mathrm{ha}^{-1}\right)$ than rest of the irrigation methods (10.87 to $11.05 \mathrm{~kg} \mathrm{ha}^{-1}$ ). Among establishment methods, manual transplanting recorded significantly higher phosphorus uptake by grain $\left(13.80 \mathrm{~kg} \mathrm{ha}^{-1}\right)$ followed by mechanical transplanting $\left(12.45 \mathrm{~kg} \mathrm{ha}^{-1}\right)$ as compared to rest of the methods (7.04 to $\left.11.50 \mathrm{~kg} \mathrm{ha}^{-1}\right)$. Among interactions, alternate wetting and drying up to PI followed by flooding after PI with manual transplanting recorded significantly higher phosphorus uptake by grain $\left(16.85 \mathrm{~kg} \mathrm{ha}^{-1}\right)$ followed by alternate wetting and drying up to PI followed by flooding after PI with mechanical transplanting $\left(15.13 \mathrm{~kg} \mathrm{ha}^{-1}\right)$ over rest of the interactions (6.17 to $14.02 \mathrm{~kg} \mathrm{ha}^{-1}$ ). Effective absorption of nutrients was seen under early established seedlings. This might be due to the well developed root system. The results are in close agreement with the findings of Dass and Chandra, (2012).

\section{Phosphorus uptake by rice straw $\left(\mathrm{Kg} \mathrm{ha}^{-1}\right)$}

No significant difference was observed in different irrigation methods. However, higher phosphorus uptake by straw $\left(9.37 \mathrm{~kg} \mathrm{ha}^{-1}\right)$ was recorded by alternate wetting and drying 
up to PI followed by flooding after PI followed by maintenance of saturation up to PI followed by flooding after PI $\left(8.83 \mathrm{~kg} \mathrm{ha}^{-1}\right)$ and continuous flooding $\left(8.46 \mathrm{~kg} \mathrm{ha}^{-1}\right)$. Mechanical transplanting recorded significantly higher phosphorus uptake by straw $\left(11.02 \mathrm{~kg} \mathrm{ha}^{-1}\right)$ as compared to rest of the methods ( 7.44 to $9.00 \mathrm{~kg} \mathrm{ha}^{-1}$ ). Interaction between alternate wetting and drying up to PI followed by flooding after PI and mechanical transplanting recorded significantly higher phosphorus uptake by straw $\left(11.98 \mathrm{~kg} \mathrm{ha}^{-1}\right)$ which was closely followed by continuous flooding with mechanical transplanting (10.86 $\mathrm{kg} \mathrm{ha}^{-1}$ ) over rest of the interactions (6.75 to $10.64 \mathrm{~kg} \mathrm{ha}^{-1}$ ).

Continuous flooding brought the phosphorus to available form and hence the uptake was more. Whereas, in case of alternate wetting and drying, plant roots were successful in excavating the soil and hence increase in uptake of phosphorus present around the plant roots. Similar results were reported in the findings of Chandrapala et al., (2010).

\section{Total phosphorus uptake ( $\mathrm{Kg} \mathrm{ha}^{-1}$ )}

Total phosphorus uptake was higher in alternate wetting and drying up to PI followed by flooding after PI (20.24 $\left.\mathrm{kg} \mathrm{ha}^{-1}\right)$ and the effect was non significant when compared to rest of the methods (19.79 to $19.88 \mathrm{~kg} \mathrm{ha}^{-1}$ ). Among establishment methods, mechanical transplanting recorded significantly higher total phosphorus uptake (23.46 $\left.\mathrm{kg} \mathrm{ha}^{-1}\right)$ followed by manual transplanting $(22.76 \mathrm{~kg}$ $\mathrm{ha}^{-1}$ ) as compared to rest of the methods (14.48 to $20.50 \mathrm{~kg} \mathrm{ha}^{-1}$ ). This may be due to the synchrony between supply and uptake of nutrients through proliferated root system (Chandrapala et al., 2010). Among interactions, alternate wetting and drying up to PI followed by flooding after PI with manual transplanting recorded significantly higher total phosphorus uptake (27.49 $\left.\mathrm{kg} \mathrm{ha}^{-1}\right)$ followed by alternate wetting and drying up to PI followed by flooding after PI with mechanical transplanting $\left(27.11 \mathrm{~kg} \mathrm{ha}^{-1}\right)$ as compared to rest of the interactions (13.15 to $23.88 \mathrm{~kg} \mathrm{ha}^{-1}$ ).

\section{Potassium uptake by rice grain $\left(\mathrm{kg} \mathrm{ha}^{-1}\right)$}

Data on potassium uptake as influenced by irrigation methods and establishment methods are presented in Table 5. Irrigation had no significant effect on potassium uptake by grain. However, alternate wetting and drying up to PI followed by flooding after PI recorded higher potassium uptake by grain (47.43 $\mathrm{kg} \mathrm{ha}^{-1}$ ) among irrigation methods. Manual transplanting recorded significantly higher potassium uptake by grain $(48.68 \mathrm{~kg}$ $\mathrm{ha}^{-1}$ ) followed by mechanical transplanting (48.06 $\mathrm{kg} \mathrm{ha}^{-1}$ ) and semi dry rice $(47.64 \mathrm{~kg} \mathrm{ha}$ $\left.{ }^{1}\right)$ over rest of the establishment methods (45.59 to $47.08 \mathrm{~kg} \mathrm{ha}^{-1}$ ). Potassium uptake by the crop is influenced by potassium content and dry matter production, so significant difference was found as confirmed by the findings of Rani and Sukumari (2013).

Among interactions, alternate wetting and drying up to PI followed by flooding after PI with manual transplanting recorded significantly higher potassium uptake by grain (50.01 kg ha ${ }^{-1}$ ) followed by alternate wetting and drying up to PI followed by flooding after PI with mechanical transplanting $(49.56 \mathrm{~kg}$ $\mathrm{ha}^{-1}$ ) and maintenance of saturation up to PI followed by flooding after PI with manual transplanting $\left(49.21 \mathrm{~kg} \mathrm{ha}^{-1}\right)$ as compared to rest of the interactions (45.16 to 48.84 $\mathrm{kg} \mathrm{ha}^{-1}$ ).

\section{Potassium uptake by rice straw (kg ha $\left.{ }^{-1}\right)$}

Different irrigation methods have no significant effect on potassium uptake by straw. However, alternate wetting and drying up to PI followed by flooding after PI 
recorded higher potassium uptake by straw (73.16 kg ha $\mathrm{kg}^{-1}$. Mechanical transplanting recorded significantly higher potassium uptake by straw $\left(76.52 \mathrm{~kg} \mathrm{ha}^{-1}\right)$ over rest of the establishment methods (69.03 to $72.28 \mathrm{~kg}$ $\mathrm{ha}^{-1}$ ).

Mechanical transplanting produced higher dry matter which may be due to the effective absorption of the potassium by plants. Similar results were reported by Hugar et al., (2009). Interaction between alternate wetting and drying up to PI followed by flooding after PI and mechanical transplanting recorded significantly higher potassium uptake by straw $\left(78.82 \mathrm{~kg} \mathrm{ha}^{-1}\right)$ as compared to rest of the interactions (68.42 to $75.98 \mathrm{~kg} \mathrm{ha}^{-1}$ ).

\section{Total potassium uptake $\left(\mathrm{kg} \mathrm{ha}^{-1}\right)$}

No significant variations were found among irrigation methods with respect to total potassium uptake. Among establishment methods, mechanical transplanting recorded significantly higher total potassium uptake $\left(124.58 \mathrm{~kg} \mathrm{ha}^{-1}\right)$ as compared to rest of the methods (114.62 to $120.96 \mathrm{~kg} \mathrm{ha}^{-1}$ ). The results obtained are in conformity with the earlier findings of Jayadeva and Prabhakara Shetty (2008) and Satyanarayana and Babu, (2004).

Among interactions, AWD with mechanical transplanting recorded significantly higher total potassium uptake (128.38 $\left.\mathrm{kg} \mathrm{ha}^{-1}\right)$ followed by alternate wetting and drying up to PI followed by flooding after PI with manual transplanting (125.99 $\left.\mathrm{kg} \mathrm{ha}^{-1}\right)$ over rest of the interactions (113.27 to $124.59 \mathrm{~kg} \mathrm{ha}^{-1}$ ).

\section{Chemical properties of soil after harvest}

The data on $\mathrm{pH}, \mathrm{EC}\left(\mathrm{dSm}^{-1}\right)$, organic carbon (per cent OC) and available nutrient status of the soil $\left(\mathrm{kg} \mathrm{ha}^{-1}\right)$ is presented in table 6 .
pH, EC and per cent OC of soil after harvest of crop

Among irrigation methods, continuous flooding recorded higher $\mathrm{pH}$ and EC (7.92 and $0.21 \mathrm{dS} \mathrm{m}^{-1}$, respectively) which were on par with alternate wetting and drying up to PI followed by flooding after PI (7.86 and 0.20 $\mathrm{dS} \mathrm{m}^{-1}$, respectively) and maintenance of saturation up to PI followed by flooding after PI (7.84 and $0.20 \mathrm{dS} \mathrm{m}^{-1}$, respectively). However, AWD recorded higher OC $(0.62 \%)$ and was at par with rest of the methods $(0.56$ to $0.61 \%$ ). Among establishment methods, drum seeded rice recorded higher $\mathrm{pH}$ and EC (8.05 and $0.21 \mathrm{dS} \mathrm{m}^{-1}$, respectively) while semi dry rice recorded higher OC $(0.68 \%)$ and were statistically on par with rest of the methods. Interaction effect between irrigation methods and establishment methods was not significant with respect to $\mathrm{pH}, \mathrm{EC}$ and per cent OC.

\section{Available nitrogen status of the soil ( $\mathrm{kg} \mathrm{ha}^{-}$ 1)}

Alternate wetting and drying up to PI followed by flooding after PI recorded higher available nitrogen content in soil $(274.19 \mathrm{~kg}$ $\mathrm{ha}^{-1}$ ) whereas, continuous flooding recorded lower available nitrogen content in soil $\left(248.27 \mathrm{~kg} \mathrm{ha}^{-1}\right)$. This may be due to the various forms of nitrogen losses under submerged condition (Taiz and Zeiger, 2006). Among establishment methods, both drum seeded rice and broadcasting of sprouted rice recorded higher available nitrogen content in soil $\left(264.15 \mathrm{~kg} \mathrm{ha}^{-1}\right)$ and was on par with rest of the methods of establishment (253 to $\left.259.97 \mathrm{~kg} \mathrm{ha}^{-1}\right)$. The results are in line with Chandrapala et al., (2010). Among interactions, alternate wetting and drying up to PI followed by flooding after PI with broadcasting of sprouted rice recorded higher available nitrogen content in soil $(293.42 \mathrm{~kg}$ $\mathrm{ha}^{-1}$ ) and effect was non significant. 
Table.1 Leaf area at different growth stages and at harvest as influenced by irrigation management practices and establishment methods in rice

\begin{tabular}{|c|c|c|c|c|}
\hline \multirow[t]{3}{*}{ Treatment } & \multicolumn{4}{|c|}{ Leaf area $\left(\mathrm{cm}^{2} \mathrm{hill}^{-1}\right)$} \\
\hline & \multicolumn{3}{|c|}{ DAS } & \multirow[t]{2}{*}{ At harvest } \\
\hline & 30 & 60 & 90 & \\
\hline \multicolumn{5}{|l|}{ Irrigation methods (I) } \\
\hline $\mathbf{I}_{1}$ : Continuous flooding & 94.51 & 605.80 & 1059.29 & 836.62 \\
\hline $\begin{array}{l}\mathbf{I}_{2} \text { : Maintenance of saturation up to } \\
\text { panicle initiation (PI)followed by } \\
\text { flooding after PI }\end{array}$ & 82.32 & 596.49 & 1133.55 & 831.22 \\
\hline $\begin{array}{l}\text { I }_{3} \text { Alternate wetting and drying up } \\
\text { to PI followed by flooding } 5 \pm 2 \mathrm{~cm}\end{array}$ & 82.94 & 544.58 & 1228.46 & 920.61 \\
\hline S.Em. \pm & 3.33 & 13.62 & 21.65 & 11.03 \\
\hline$C D(p=0.05)$ & NS & NS & 84.81 & 43.21 \\
\hline \multicolumn{5}{|l|}{ Rice establishment methods (E) } \\
\hline $\mathbf{E}_{1}$ : Drum seeded rice & 67.53 & 502.56 & 985.53 & 822.65 \\
\hline$E_{2}$ : Broadcasting of sprouted rice & 102.83 & 626.78 & 899.88 & 745.55 \\
\hline$E_{3}:$ Semi dry rice & 165.62 & 485.08 & 1147.31 & 880.98 \\
\hline $\mathbf{E}_{4}:$ Mechanical transplanting & 13.91 & 721.85 & 1528.53 & 1020.46 \\
\hline $\mathbf{E}_{5}:$ Manual transplanting & 83.06 & 575.16 & 1140.91 & 844.44 \\
\hline S.Em. \pm & 3.70 & 15.56 & 18.98 & 17.68 \\
\hline$C D(p=0.05)$ & 10.81 & 45.42 & 55.40 & 51.60 \\
\hline \multicolumn{5}{|l|}{ Interaction } \\
\hline $\mathbf{I}_{1} \mathbf{E}_{1}$ & 75.57 & 439.33 & 1051.31 & 895.31 \\
\hline $\mathbf{I}_{1} \mathbf{E}_{2}$ & 110.20 & 684.64 & 1000.11 & 889.81 \\
\hline $\mathbf{I}_{1} \mathbf{E}_{3}$ & 191.71 & 405.34 & 977.71 & 810.38 \\
\hline $\mathbf{I}_{1} \mathbf{E}_{4}$ & 12.26 & 854.08 & 1555.95 & 981.59 \\
\hline $\mathbf{I}_{1} \mathbf{E}_{5}$ & 82.80 & 645.59 & 711.36 & 606.02 \\
\hline $\mathbf{I}_{2} \mathbf{E}_{1}$ & 75.05 & 641.11 & 910.08 & 701.61 \\
\hline $\mathbf{I}_{2} \mathbf{E}_{2}$ & 92.99 & 618.68 & 807.68 & 644.63 \\
\hline $\mathbf{I}_{2} \mathbf{E}_{3}$ & 141.88 & 512.20 & 1326.51 & 937.00 \\
\hline $\mathbf{I}_{2} \mathbf{E}_{4}$ & 13.51 & 601.55 & 1389.55 & 934.27 \\
\hline $\mathbf{I}_{2} \mathbf{E}_{5}$ & 88.15 & 608.91 & 1233.92 & 938.60 \\
\hline $\mathbf{I}_{3} \mathbf{E}_{1}$ & 51.97 & 427.25 & 995.20 & 871.04 \\
\hline $\mathbf{I}_{3} \mathbf{E}_{2}$ & 105.29 & 577.01 & 891.84 & 702.22 \\
\hline $\mathbf{I}_{3} \mathbf{E}_{3}$ & 163.28 & 537.72 & 1137.71 & 895.57 \\
\hline $\mathbf{I}_{3} \mathbf{E}_{4}$ & 15.95 & 709.92 & 1640.11 & 1145.52 \\
\hline $\mathbf{I}_{3} \mathbf{E}_{5}$ & 78.24 & 470.98 & 1477.44 & 988.69 \\
\hline S.Em. \pm & 6.63 & 27.69 & 36.51 & 29.52 \\
\hline $\operatorname{CD}(p=0.05)$ & 18.72 & 78.67 & 95.95 & 89.37 \\
\hline
\end{tabular}

Note: NS - Non significant 
Table.2 Dry matter production at different growth stages and at harvest as influenced by irrigation management practices and establishment methods in rice

\begin{tabular}{|c|c|c|c|c|c|}
\hline \multirow[t]{3}{*}{ Treatment } & \multicolumn{4}{|c|}{ Dry matter production(g hill $\left.{ }^{-1}\right)$} & \multirow{3}{*}{$\underset{\substack{\text { Grain } \\
\text { yield } \\
\left(\mathbf{k g ~ h a}^{-1}\right)}}{(}$} \\
\hline & \multicolumn{3}{|c|}{ DAS } & \multirow{2}{*}{ At harvest } & \\
\hline & 30 & 60 & 90 & & \\
\hline \multicolumn{6}{|l|}{ Irrigation methods (I) } \\
\hline $\mathbf{I}_{1}$ : Continuous flooding & 1.82 & 12.62 & 33.10 & 64.36 & 4916 \\
\hline $\begin{array}{l}\text { I }_{2} \text { : Maintenance of saturation up to } \\
\text { panicle initiation (PI)followed by } \\
\text { flooding after PI }\end{array}$ & 1.58 & 12.43 & 35.42 & 63.94 & 4828 \\
\hline $\begin{array}{l}\text { I }_{3:} \text { Alternate wetting and drying up to PI } \\
\text { followed by flooding } 3 \pm 2 \mathrm{~cm}\end{array}$ & 1.60 & 11.35 & 38.39 & 70.82 & 4849 \\
\hline S.Em \pm & 0.06 & 0.28 & 0.68 & 0.85 & 190 \\
\hline $\mathrm{CD}(\overline{\mathrm{p}}=0.05)$ & NS & NS & 2.65 & 3.32 & NS \\
\hline \multicolumn{6}{|l|}{ Rice establishment methods (E) } \\
\hline$E_{1}$ : Drum seeded rice & 1.30 & 10.47 & 30.80 & 63.28 & 4749 \\
\hline $\mathbf{E}_{2}$ : Broadcasting of sprouted rice & 1.98 & 13.06 & 28.12 & 57.35 & 4197 \\
\hline$E_{3}$ : Semi dry rice & 3.19 & 10.11 & 35.85 & 67.77 & 4953 \\
\hline $\mathbf{E}_{4}$ : Mechanical transplanting & 0.27 & 15.04 & 47.77 & 78.50 & 5171 \\
\hline $\mathbf{E}_{5}:$ Manual transplanting & 1.60 & 11.98 & 35.65 & 64.96 & 5253 \\
\hline S.Em \pm & 0.07 & 0.32 & 0.59 & 1.36 & 121 \\
\hline $\mathrm{CD}(\mathrm{p}=0.05)$ & 0.21 & 0.95 & 1.73 & 3.97 & 354 \\
\hline \multicolumn{6}{|l|}{ Interaction } \\
\hline $\mathbf{I}_{1} \mathbf{E}_{1}$ & 1.59 & 12.69 & 32.85 & 68.87 & 4932 \\
\hline $\mathbf{I}_{1} \mathbf{E}_{2}$ & 1.44 & 12.53 & 31.25 & 68.45 & 4544 \\
\hline $\mathbf{I}_{1} \mathbf{E}_{3}$ & 1.50 & 10.67 & 30.55 & 62.34 & 5189 \\
\hline $\mathbf{I}_{1} \mathbf{E}_{4}$ & 3.14 & 14.26 & 48.62 & 75.51 & 5104 \\
\hline $\mathbf{I}_{1} \mathbf{E}_{5}$ & 0.24 & 8.44 & 22.23 & 46.62 & 4811 \\
\hline $\mathbf{I}_{2} \mathbf{E}_{1}$ & 0.31 & 9.81 & 28.44 & 53.97 & 5137 \\
\hline $\mathbf{I}_{2} \mathbf{E}_{2}$ & 0.26 & 9.15 & 25.24 & 49.59 & 3953 \\
\hline $\mathbf{I}_{2} \mathbf{E}_{3}$ & 1.79 & 13.36 & 41.45 & 72.08 & 5050 \\
\hline $\mathbf{I}_{2} \mathbf{E}_{4}$ & 2.12 & 13.45 & 43.42 & 71.87 & 4797 \\
\hline $\mathbf{I}_{2} \mathbf{E}_{5}$ & 2.02 & 12.89 & 38.56 & 72.20 & 5202 \\
\hline $\mathbf{I}_{3} \mathbf{E}_{1}$ & 1.45 & 11.20 & 31.10 & 67.00 & 4177 \\
\hline $\mathbf{I}_{3} \mathbf{E}_{2}$ & 1.00 & 8.90 & 27.87 & 54.02 & 4093 \\
\hline $\mathbf{I}_{3} \mathbf{E}_{3}$ & 1.70 & 12.02 & 35.55 & 68.89 & 4619 \\
\hline $\mathbf{I}_{3} \mathbf{E}_{4}$ & 3.69 & 17.79 & 51.25 & 88.12 & 5613 \\
\hline $\mathbf{I}_{3} \mathbf{E}_{5}$ & 2.73 & 14.79 & 46.17 & 76.05 & 5745 \\
\hline S.Em \pm & 0.13 & 0.58 & 1.14 & 2.27 & 267 \\
\hline $\mathrm{CD}(\overline{\mathrm{p}}=0.05)$ & 0.36 & 1.64 & 3.00 & 6.87 & 614 \\
\hline
\end{tabular}

Note: NS - Non significant 
Table.3 Nitrogen uptake at harvest as influenced by irrigation management practices and establishment methods in rice

\begin{tabular}{|c|c|c|c|}
\hline \multirow[t]{2}{*}{ Treatments } & \multicolumn{3}{|c|}{ N uptake $\left(\mathrm{kg} \mathrm{ha}^{-1}\right)$} \\
\hline & Grain & Straw & Total \\
\hline \multicolumn{4}{|l|}{ Irrigation methods (I) } \\
\hline $\mathbf{I}_{1}$ : Continuous flooding & 61.51 & 56.85 & 118.36 \\
\hline $\begin{array}{l}\mathbf{I}_{2} \text { : Maintenance of saturation up to } \\
\text { panicle initiation (PI)followed by flooding } \\
\text { after PI }\end{array}$ & 60.88 & 57.14 & 118.02 \\
\hline $\begin{array}{l}I_{3:} \text { Alternate wetting and drying up to PI } \\
\text { followed by flooding } 3 \pm 2 \mathrm{~cm}\end{array}$ & 61.52 & 58.64 & 120.16 \\
\hline S.Em \pm & 0.78 & 0.58 & 1.30 \\
\hline $\mathrm{CD}(\mathrm{p}=0.05)$ & NS & NS & NS \\
\hline \multicolumn{4}{|l|}{ Rice establishment methods (E) } \\
\hline$E_{1}$ : Drum seeded rice & 60.27 & 56.13 & 116.40 \\
\hline$E_{2}:$ Broadcasting of sprouted rice & 54.08 & 54.91 & 108.99 \\
\hline$E_{3}$ : Semi dry rice & 61.93 & 57.53 & 119.46 \\
\hline $\mathrm{E}_{4}$ : Mechanical transplanting & 63.74 & 61.86 & 125.60 \\
\hline$E_{5}:$ Manual transplanting & 66.49 & 57.30 & 123.79 \\
\hline S.Em \pm & 0.49 & 0.32 & 0.56 \\
\hline $\mathrm{CD}(\mathrm{p}=0.05)$ & 1.43 & 0.93 & 1.65 \\
\hline \multicolumn{4}{|l|}{ Interaction } \\
\hline $\mathbf{I}_{1} \mathbf{E}_{1}$ & 61.83 & 57.52 & 119.35 \\
\hline $\mathbf{I}_{1} \mathbf{E}_{2}$ & 57.11 & 56.09 & 115.43 \\
\hline $\mathbf{I}_{1} \mathbf{E}_{3}$ & 64.89 & 55.74 & 120.63 \\
\hline $\mathbf{I}_{1} \mathbf{E}_{4}$ & 63.51 & 61.92 & 125.43 \\
\hline $\mathbf{I}_{1} \mathbf{E}_{5}$ & 60.21 & 52.99 & 113.20 \\
\hline $\mathbf{I}_{2} \mathbf{E}_{1}$ & 64.12 & 54.95 & 119.07 \\
\hline $\mathbf{I}_{2} \mathbf{E}_{2}$ & 52.01 & 54.07 & 109.08 \\
\hline $\mathbf{I}_{2} \mathbf{E}_{3}$ & 62.69 & 59.11 & 121.80 \\
\hline $\mathbf{I}_{2} \mathbf{E}_{4}$ & 59.57 & 59.46 & 119.36 \\
\hline $\mathbf{I}_{2} \mathbf{E}_{5}$ & 66.02 & 58.12 & 124.14 \\
\hline $\mathbf{I}_{3} \mathbf{E}_{1}$ & 54.86 & 55.91 & 111.44 \\
\hline $\mathbf{I}_{3} \mathbf{E}_{2}$ & 53.13 & 54.56 & 111.02 \\
\hline $\mathbf{I}_{3} \mathbf{E}_{3}$ & 58.22 & 57.74 & 115.96 \\
\hline $\mathbf{I}_{3} \mathbf{E}_{4}$ & 68.13 & 64.20 & 132.33 \\
\hline $\mathbf{I}_{3} \mathbf{E}_{5}$ & 73.25 & 60.79 & 134.04 \\
\hline S.Em \pm & 1.09 & 0.76 & 1.56 \\
\hline $\mathrm{CD}(\mathrm{p}=0.05)$ & 2.48 & 1.62 & 2.85 \\
\hline
\end{tabular}

Note: NS - Non significant 
Table.4 Phosphorus uptake at harvest as influenced by irrigation management practices and establishment methods in rice

\begin{tabular}{|c|c|c|c|}
\hline \multirow[t]{2}{*}{ Treatments } & \multicolumn{3}{|c|}{ P uptake $\left(\mathrm{kg} \mathrm{ha}^{-1}\right)$} \\
\hline & Grain & Straw & Total \\
\hline \multicolumn{4}{|l|}{ Irrigation methods (I) } \\
\hline $\mathbf{I}_{1}$ : Continuous flooding & 11.33 & 8.46 & 19.79 \\
\hline $\begin{array}{l}\mathbf{I}_{2} \text { : Maintenance of saturation up to panicle } \\
\text { initiation (PI)followed by flooding after PI }\end{array}$ & 11.05 & 8.83 & 19.88 \\
\hline $\begin{array}{l}I_{3} \text { : Alternate wetting and drying up to PI followed } \\
\text { by flooding } 3 \pm 2 \mathrm{~cm}\end{array}$ & 10.87 & 9.37 & 20.24 \\
\hline S.Em \pm & 0.59 & 0.31 & 0.88 \\
\hline $\mathrm{CD}(\mathrm{p}=\mathbf{0 . 0 5})$ & NS & NS & NS \\
\hline \multicolumn{4}{|l|}{ Rice establishment methods (E) } \\
\hline$E_{1}:$ Drum seeded rice & 10.62 & 8.02 & 18.64 \\
\hline$E_{2}$ : Broadcasting of sprouted rice & 7.04 & 7.44 & 14.48 \\
\hline$E_{3}:$ Semi dry rice & 11.50 & 9.00 & 20.50 \\
\hline $\mathbf{E}_{4}$ : Mechanical transplanting & 12.45 & 11.02 & 23.46 \\
\hline E$_{5}:$ Manual transplanting & 13.80 & 8.96 & 22.76 \\
\hline S.Em \pm & 0.51 & 0.30 & 0.55 \\
\hline $\mathrm{CD}(\overline{\mathrm{p}}=0.05)$ & 1.48 & 0.88 & 1.61 \\
\hline \multicolumn{4}{|l|}{ Interaction } \\
\hline $\mathbf{I}_{1} \mathbf{E}_{1}$ & 11.52 & 8.58 & 20.10 \\
\hline $\mathbf{I}_{1} \mathbf{E}_{2}$ & 7.99 & 8.21 & 16.20 \\
\hline $\mathbf{I}_{1} \mathbf{E}_{3}$ & 13.58 & 7.89 & 21.47 \\
\hline $\mathbf{I}_{1} \mathbf{E}_{4}$ & 13.02 & 10.86 & 23.88 \\
\hline $\mathbf{I}_{1} \mathbf{E}_{5}$ & 10.53 & 6.75 & 17.28 \\
\hline $\mathbf{I}_{2} \mathbf{E}_{1}$ & 13.21 & 7.44 & 20.65 \\
\hline $\mathbf{I}_{2} \mathbf{E}_{2}$ & 6.17 & 6.98 & 13.15 \\
\hline $\mathbf{I}_{2} \mathbf{E}_{3}$ & 12.65 & 10.05 & 22.70 \\
\hline $\mathbf{I}_{2} \mathbf{E}_{4}$ & 9.19 & 10.21 & 19.40 \\
\hline $\mathbf{I}_{2} \mathbf{E}_{5}$ & 14.02 & 9.49 & 23.51 \\
\hline $\mathbf{I}_{3} \mathbf{E}_{1}$ & 7.14 & 8.03 & 15.17 \\
\hline $\mathbf{I}_{3} \mathbf{E}_{2}$ & 6.96 & 7.12 & 14.08 \\
\hline $\mathbf{I}_{3} \mathbf{E}_{3}$ & 8.26 & 9.07 & 17.33 \\
\hline $\mathbf{I}_{3} \mathbf{E}_{4}$ & 15.13 & 11.98 & 27.11 \\
\hline $\mathbf{I}_{3} \mathbf{E}_{5}$ & 16.85 & 10.64 & 27.49 \\
\hline S.Em \pm & 0.98 & 0.56 & 1.23 \\
\hline $\mathrm{CD}(\mathrm{p}=0.05)$ & 2.57 & 1.52 & 2.78 \\
\hline
\end{tabular}

Note: NS - Non significant 
Table.5 Potassium uptake at harvest as influenced by irrigation management practices and establishment methods in rice

\begin{tabular}{|c|c|c|c|}
\hline \multirow[t]{2}{*}{ Treatments } & \multicolumn{3}{|c|}{ K uptake (kg ha $\left.{ }^{-1}\right)$} \\
\hline & Grain & Straw & Total \\
\hline \multicolumn{4}{|l|}{ Irrigation methods (I) } \\
\hline $\mathbf{I}_{1}$ : Continuous flooding & 47.39 & 71.14 & 118.53 \\
\hline $\begin{array}{l}\mathbf{I}_{2} \text { : Maintenance of saturation up to } \\
\text { panicle initiation (PI)followed by } \\
\text { flooding after PI }\end{array}$ & 47.40 & 71.79 & 119.19 \\
\hline $\begin{array}{l}\text { I }_{3} \text { : Alternate wetting and drying up to PI } \\
\text { followed by flooding } 3 \pm 2 \mathrm{~cm}\end{array}$ & 47.43 & 73.16 & 120.60 \\
\hline S.Em \pm & 0.31 & 0.97 & 1.07 \\
\hline $\mathrm{CD}(\mathrm{p}=0.05)$ & NS & NS & NS \\
\hline \multicolumn{4}{|l|}{ Rice establishment methods (E) } \\
\hline$E_{1}$ : Drum seeded rice & 47.08 & 70.33 & 117.41 \\
\hline$E_{2}$ : Broadcasting of sprouted rice & 45.59 & 69.03 & 114.62 \\
\hline$E_{3}$ : Semi dry rice & 47.64 & 72.00 & 119.64 \\
\hline $\mathbf{E}_{4}$ : Mechanical transplanting & 48.06 & 76.52 & 124.58 \\
\hline $\mathbf{E}_{5}$ : Manual transplanting & 48.68 & 72.28 & 120.96 \\
\hline S.Em \pm & 0.41 & 0.33 & 0.54 \\
\hline $\mathrm{CD}(\mathrm{p}=0.05)$ & 1.21 & 0.97 & 1.58 \\
\hline \multicolumn{4}{|l|}{ Interaction } \\
\hline $\mathbf{I}_{1} \mathbf{E}_{1}$ & 47.13 & 71.79 & 118.92 \\
\hline $\mathbf{I}_{1} \mathbf{E}_{2}$ & 46.08 & 70.56 & 116.64 \\
\hline $\mathbf{I}_{1} \mathbf{E}_{3}$ & 48.84 & 69.48 & 118.32 \\
\hline $\mathbf{I}_{1} \mathbf{E}_{4}$ & 48.09 & 76.50 & 124.59 \\
\hline $\mathbf{I}_{1} \mathbf{E}_{5}$ & 46.82 & 67.36 & 114.18 \\
\hline $\mathbf{I}_{2} \mathbf{E}_{1}$ & 48.23 & 68.97 & 117.20 \\
\hline $\mathbf{I}_{2} \mathbf{E}_{2}$ & 45.16 & 68.11 & 113.27 \\
\hline $\mathbf{I}_{2} \mathbf{E}_{3}$ & 47.87 & 74.17 & 122.04 \\
\hline $\mathbf{I}_{2} \mathbf{E}_{4}$ & 46.53 & 74.23 & 120.76 \\
\hline $\mathbf{I}_{2} \mathbf{E}_{5}$ & 49.21 & 73.49 & 122.70 \\
\hline $\mathbf{I}_{3} \mathbf{E}_{1}$ & 45.87 & 70.23 & 116.10 \\
\hline $\mathbf{I}_{3} \mathbf{E}_{2}$ & 45.52 & 68.42 & 113.94 \\
\hline $\mathbf{I}_{3} \mathbf{E}_{3}$ & 46.21 & 72.36 & 118.57 \\
\hline $\mathbf{I}_{3} \mathbf{E}_{4}$ & 49.56 & 78.82 & 128.38 \\
\hline $\mathbf{I}_{3} \mathbf{E}_{5}$ & 50.01 & 75.98 & 125.99 \\
\hline S.Em \pm & 0.71 & 1.09 & 1.36 \\
\hline $\mathrm{CD}(\mathrm{p}=0.05)$ & 2.10 & 1.68 & 2.74 \\
\hline
\end{tabular}

Note: NS - Non significant 
Table.6 Available nutrients status in soil after harvest as influenced by irrigation management practices and establishment methods in rice

\begin{tabular}{|c|c|c|c|c|c|c|}
\hline Treatments & pH & $\begin{array}{c}E c \\
\left(d_{S} m^{-1}\right)\end{array}$ & $\begin{array}{l}\text { OC } \\
(\%)\end{array}$ & $\begin{array}{c}\text { Available } \\
\mathbf{N} \\
\left(\mathrm{kg} \mathrm{ha}^{-1}\right)\end{array}$ & $\begin{array}{c}\text { Available } \\
\mathbf{P}_{2} \mathrm{O}_{5} \\
\left(\mathrm{~kg} \mathrm{ha}^{-1}\right)\end{array}$ & $\begin{array}{l}\text { Availabl } \\
\text { e K}_{2} \mathbf{O} \\
\left(\mathbf{k g ~ h a}^{-1}\right)\end{array}$ \\
\hline \multicolumn{7}{|l|}{ Irrigation methods (I) } \\
\hline$I_{1}$ : Continuous flooding & 7.92 & 0.21 & 0.61 & 248.27 & 97.44 & 213.23 \\
\hline $\begin{array}{l}\mathbf{I}_{2}: \text { Maintenance of saturation up } \\
\text { to panicle initiation (PI)followed } \\
\text { by flooding after PI }\end{array}$ & 7.84 & 0.20 & 0.56 & 257.46 & 99.73 & 211.50 \\
\hline $\begin{array}{l}I_{3} \text { : Alternate wetting and drying } \\
\text { up to PI followed by flooding } \\
3 \pm 2 \mathrm{~cm}\end{array}$ & 7.86 & 0.20 & 0.62 & 274.19 & 99.65 & 212.29 \\
\hline S.Em \pm & 0.13 & 0.01 & 0.01 & 8.87 & 1.02 & 2.72 \\
\hline $\mathrm{CD}(\mathrm{p}=0.05)$ & NS & NS & NS & NS & NS & NS \\
\hline \multicolumn{7}{|l|}{ Rice establishment methods (E) } \\
\hline$E_{1}$ : Drum seeded rice & 8.05 & 0.21 & 0.59 & 264.15 & 98.30 & 213.75 \\
\hline$E_{2}$ : Broadcasting of sprouted rice & 8.04 & 0.21 & 0.58 & 264.15 & 99.61 & 212.26 \\
\hline$E_{3}$ : Semi dry rice & 7.99 & 0.20 & 0.68 & 258.58 & 100.70 & 212.40 \\
\hline $\mathbf{E}_{4}$ : Mechanical transplanting & 7.43 & 0.20 & 0.49 & 259.97 & 97.15 & 213.42 \\
\hline $\mathbf{E}_{5}:$ Manual transplanting & 7.88 & 0.21 & 0.64 & 253.00 & 98.93 & 209.87 \\
\hline S.Em \pm & 0.29 & 0.01 & 0.01 & 9.04 & 1.71 & 0.92 \\
\hline $\mathrm{CD}(\mathrm{p}=0.05)$ & NS & NS & NS & NS & NS & NS \\
\hline \multicolumn{7}{|l|}{ Interaction } \\
\hline $\mathbf{I}_{1} \mathbf{E}_{1}$ & 7.99 & 0.22 & 0.53 & 259.97 & 100.17 & 213.55 \\
\hline $\mathbf{I}_{1} \mathbf{E}_{2}$ & 8.04 & 0.21 & 0.56 & 255.79 & 96.84 & 211.78 \\
\hline $\mathbf{I}_{1} \mathbf{E}_{3}$ & 7.95 & 0.22 & 0.57 & 243.25 & 94.58 & 215.36 \\
\hline $\mathbf{I}_{1} \mathbf{E}_{4}$ & 7.88 & 0.20 & 0.51 & 251.61 & 99.98 & 214.58 \\
\hline $\mathbf{I}_{1} \mathbf{E}_{5}$ & 7.76 & 0.21 & 0.55 & 230.70 & 95.63 & 210.87 \\
\hline $\mathbf{I}_{2} \mathbf{E}_{1}$ & 8.04 & 0.18 & 0.57 & 255.79 & 96.02 & 213.20 \\
\hline $\mathbf{I}_{2} \mathbf{E}_{2}$ & 8.01 & 0.21 & 0.55 & 243.25 & 100.56 & 215.28 \\
\hline $\mathbf{I}_{2} \mathbf{E}_{3}$ & 8.61 & 0.19 & 0.55 & 268.34 & 104.70 & 211.17 \\
\hline $\mathbf{I}_{2} \mathbf{E}_{4}$ & 6.61 & 0.19 & 0.54 & 255.79 & 99.47 & 210.04 \\
\hline $\mathbf{I}_{2} \mathbf{E}_{5}$ & 7.94 & 0.23 & 0.54 & 264.15 & 97.91 & 207.82 \\
\hline $\mathbf{I}_{3} \mathbf{E}_{1}$ & 8.11 & 0.22 & 0.55 & 276.70 & 98.71 & 214.51 \\
\hline $\mathbf{I}_{3} \mathbf{E}_{2}$ & 8.06 & 0.20 & 0.53 & 293.42 & 101.44 & 209.72 \\
\hline $\mathbf{I}_{3} \mathbf{E}_{3}$ & 7.40 & 0.19 & 0.54 & 264.15 & 102.82 & 210.66 \\
\hline $\mathbf{I}_{3} \mathbf{E}_{4}$ & 7.79 & 0.20 & 0.50 & 272.52 & 92.01 & 215.65 \\
\hline $\mathbf{I}_{3} \mathbf{E}_{5}$ & 7.94 & 0.20 & 0.54 & 264.15 & 103.26 & 210.92 \\
\hline S.Em \pm & 0.46 & 0.01 & 0.02 & 16.57 & 2.83 & 3.07 \\
\hline $\mathrm{CD}(\mathrm{p}=0.05)$ & NS & NS & NS & NS & NS & NS \\
\hline
\end{tabular}

Note: NS - Non significant 
Table.7 Nutrient use efficiency as influenced by irrigation management practices and establishment methods in rice

\begin{tabular}{|c|c|c|c|}
\hline Treatments & $\begin{array}{l}\text { Nitrogen use } \\
\text { efficiency } \\
\left(\mathrm{kg} \text { grain } \mathbf{k g}^{-1}\right. \\
\mathrm{N})\end{array}$ & $\begin{array}{l}\text { Phosphorus } \\
\text { use efficiency } \\
\text { (kg grain } \mathbf{k g}^{-1} \\
\left.\mathrm{P}_{2} \mathrm{O}_{5}\right)\end{array}$ & $\begin{array}{c}\text { Potassium use } \\
\text { efficiency } \\
\left(\mathrm{kg} \text { grain } \mathbf{k g}^{-1}\right. \\
\left.\mathrm{K}_{2} \mathrm{O}\right)\end{array}$ \\
\hline \multicolumn{4}{|l|}{ Irrigation methods (I) } \\
\hline $\mathbf{I}_{1}$ : Continuous flooding & 49.16 & 98.32 & 98.32 \\
\hline $\begin{array}{l}\mathrm{I}_{2} \text { : Maintenance of saturation up to } \\
\text { panicle initiation (PI)followed by } \\
\text { flooding after PI }\end{array}$ & 48.28 & 96.56 & 96.56 \\
\hline $\begin{array}{l}\text { I } \text { : Alternate wetting and drying up to } \\
\text { PI followed by flooding } 3 \pm 2 \mathrm{~cm}\end{array}$ & 48.49 & 96.99 & 96.99 \\
\hline S.Em \pm & 1.90 & 3.80 & 3.80 \\
\hline $\mathrm{CD}(\mathrm{p}=0.05)$ & NS & NS & NS \\
\hline \multicolumn{4}{|l|}{ Rice establishment methods (E) } \\
\hline$E_{1}$ : Drum seeded rice & 47.49 & 94.97 & 94.97 \\
\hline$E_{2}$ : Broadcasting of sprouted rice & 41.97 & 83.93 & 83.93 \\
\hline$E_{3}:$ Semi dry rice & 49.53 & 99.06 & 99.06 \\
\hline $\mathbf{E}_{4}$ : Mechanical transplanting & 51.71 & 103.43 & 103.43 \\
\hline $\mathbf{E}_{5}:$ Manual transplanting & 52.53 & 105.05 & 105.05 \\
\hline S.Em \pm & 1.21 & 2.43 & 2.43 \\
\hline $\mathrm{CD}(\mathrm{p}=0.05)$ & 3.54 & 7.09 & 7.09 \\
\hline \multicolumn{4}{|l|}{ Interaction } \\
\hline $\mathbf{I}_{1} \mathbf{E}_{1}$ & 49.32 & 98.64 & 98.64 \\
\hline $\mathbf{I}_{1} \mathbf{E}_{2}$ & 45.44 & 90.88 & 90.88 \\
\hline $\mathbf{I}_{1} \mathbf{E}_{3}$ & 51.89 & 103.78 & 103.78 \\
\hline $\mathbf{I}_{1} \mathbf{E}_{4}$ & 51.04 & 102.08 & 102.08 \\
\hline $\mathbf{I}_{1} \mathbf{E}_{5}$ & 48.11 & 96.21 & 96.21 \\
\hline $\mathbf{I}_{2} \mathbf{E}_{1}$ & 51.37 & 102.73 & 102.73 \\
\hline $\mathbf{I}_{2} \mathbf{E}_{2}$ & 39.53 & 79.06 & 79.06 \\
\hline $\mathbf{I}_{2} \mathbf{E}_{3}$ & 50.50 & 101.01 & 101.01 \\
\hline $\mathbf{I}_{2} \mathbf{E}_{4}$ & 47.97 & 95.94 & 95.94 \\
\hline $\mathbf{I}_{2} \mathbf{E}_{5}$ & 52.02 & 104.05 & 104.05 \\
\hline $\mathbf{I}_{3} \mathbf{E}_{1}$ & 41.77 & 83.54 & 83.54 \\
\hline $\mathbf{I}_{3} \mathbf{E}_{2}$ & 40.93 & 81.86 & 81.86 \\
\hline $\mathbf{I}_{3} \mathbf{E}_{3}$ & 46.19 & 92.38 & 92.38 \\
\hline $\mathbf{I}_{3} \mathbf{E}_{4}$ & 56.13 & 112.26 & 112.26 \\
\hline $\mathbf{I}_{3} \mathbf{E}_{5}$ & 57.45 & 114.89 & 114.89 \\
\hline S.Em \pm & 2.67 & 5.35 & 5.35 \\
\hline $\mathrm{CD}(\overline{p=0.05)}$ & 6.14 & 12.27 & 12.27 \\
\hline
\end{tabular}

Note: NS - Non significant 
Table.8 Economics as influenced by irrigation management practices and establishment methods in rice

\begin{tabular}{|c|c|c|c|c|}
\hline Treatments & $\begin{array}{c}\text { Cost of } \\
\text { cultivation } \\
\left(\square \mathbf{h a}^{-1}\right)\end{array}$ & $\begin{array}{l}\text { Gross } \\
\text { returns } \\
\left(\square \mathbf{h a}^{-1}\right)\end{array}$ & $\begin{array}{l}\text { Net returns } \\
\quad\left(\square \mathbf{h a}^{-1}\right)\end{array}$ & B: C ratio \\
\hline \multicolumn{5}{|l|}{ Irrigation methods (I) } \\
\hline $\mathbf{I}_{1}$ : Continuous flooding & 45850 & 84777 & 38927 & 1.86 \\
\hline $\begin{array}{l}\text { I }_{2} \text { : Maintenance of saturation up } \\
\text { to panicle initiation (PI) followed } \\
\text { by flooding after PI }\end{array}$ & 43650 & 83634 & 39984 & 1.92 \\
\hline $\begin{array}{l}\mathrm{I}_{3:} \text { Alternate wetting and drying } \\
\text { up to PI followed by flooding } \\
3 \pm 2 \mathrm{~cm}\end{array}$ & 42050 & 84545 & 42495 & 2.00 \\
\hline \multicolumn{5}{|l|}{ Rice establishment methods (E) } \\
\hline$E_{1}:$ Drum seeded rice & 42840 & 81955 & 39115 & 1.91 \\
\hline $\begin{array}{l}E_{2} \text { : Broadcasting of sprouted } \\
\text { rice }\end{array}$ & 42590 & 72832 & 30242 & 1.71 \\
\hline$E_{3}:$ Semi dry rice & 40390 & 85574 & 45184 & 2.12 \\
\hline $\mathbf{E}_{4}$ : Mechanical transplanting & 46065 & 90680 & 44615 & 1.97 \\
\hline $\mathbf{E}_{5}$ : Manual transplanting & 47365 & 90552 & 43187 & 1.92 \\
\hline \multicolumn{5}{|l|}{ Interaction } \\
\hline $\mathbf{I}_{1} \mathbf{E}_{1}$ & 44840 & 85191 & 40351 & 1.90 \\
\hline $\mathbf{I}_{1} \mathbf{E}_{2}$ & 44590 & 78863 & 34273 & 1.77 \\
\hline $\mathbf{I}_{1} \mathbf{E}_{3}$ & 42390 & 88572 & 46182 & 2.09 \\
\hline $\mathbf{I}_{1} \mathbf{E}_{4}$ & 48065 & 88855 & 40790 & 1.85 \\
\hline $\mathbf{I}_{1} \mathbf{E}_{5}$ & 49365 & 82406 & 33041 & 1.67 \\
\hline $\mathbf{I}_{2} \mathbf{E}_{1}$ & 42640 & 87694 & 45054 & 2.06 \\
\hline $\mathbf{I}_{2} \mathbf{E}_{2}$ & 42390 & 68681 & 26291 & 1.62 \\
\hline $\mathbf{I}_{2} \mathbf{E}_{3}$ & 40190 & 87804 & 47614 & 2.18 \\
\hline $\mathbf{I}_{2} \mathbf{E}_{4}$ & 45865 & 83809 & 37944 & 1.83 \\
\hline $\mathbf{I}_{2} \mathbf{E}_{5}$ & 47165 & 90181 & 43016 & 1.91 \\
\hline $\mathbf{I}_{3} \mathbf{E}_{1}$ & 41040 & 72980 & 31940 & 1.78 \\
\hline $\mathbf{I}_{3} \mathbf{E}_{2}$ & 40790 & 70952 & 30162 & 1.74 \\
\hline $\mathbf{I}_{3} \mathbf{E}_{3}$ & 38590 & 80346 & 41756 & 2.08 \\
\hline $\mathbf{I}_{3} \mathbf{E}_{4}$ & 44265 & 99377 & 55112 & 2.25 \\
\hline $\mathbf{I}_{3} \mathbf{E}_{5}$ & 45565 & 99068 & 53503 & 2.17 \\
\hline
\end{tabular}

Note: NS - Non significant

Available phosphorus status of the soil (kg ha $^{-1}$ )

Among irrigation methods, maintenance of saturation up to PI followed by flooding after
PI recorded higher available phosphorus content in soil $\left(99.73 \mathrm{~kg} \mathrm{ha}^{-1}\right)$ an was at par with alternate wetting and drying up to PI followed by flooding after PI $\left(99.65 \mathrm{~kg} \mathrm{ha}^{-1}\right)$ and continuous flooding $\left(97.44 \mathrm{~kg} \mathrm{ha}^{-1}\right)$. This 
can be attributed to lower uptake of phosphorus by grain and straw which was due to higher available phosphorus in soil after harvest of rice crop as confirmed in this study. These results are also in accordance with the findings of Jat et al., (2015). Semi dry rice recorded higher available phosphorus content in soil $(100.70 \mathrm{~kg} \mathrm{ha})^{-1}$ followed by broadcasting of sprouted rice $\left(99.61 \mathrm{~kg} \mathrm{ha}^{-1}\right.$ ) while mechanical transplanting recorded lower available phosphorus content in soil $\left(97.15 \mathrm{~kg} \mathrm{ha}^{-1}\right)$. Similar results were recorded by Jat et al., (2015). Interaction between irrigation and establishment methods had no significant effect on available phosphorus content in soil.

Available potassium status of the soil (kg $\mathrm{ha}^{-1}$ )

Higher available potassium content in soil (213.23 $\mathrm{kg} \mathrm{ha}^{-1}$ ) was recorded in continuous flooding. Whereas, lower available potassium content in soil (211.50 kg ha $\left.{ }^{-1}\right)$ was recorded under maintenance of saturation up to PI followed by flooding after PI. The results are in conformity with the findings of Jayadeva and Prabhakara Shetty (2008). Drum seeded rice recorded higher available potassium content in soil (213.75 kg ha-1) and the effect was non significant when compared to rest of the methods. This may be due to poor uptake of nutrient from the soil (Chandrapala et al., 2010). Among interactions, alternate wetting and drying up to PI followed by flooding after PI with mechanical transplanting recorded higher available potassium content in soil $\left(215.65 \mathrm{~kg} \mathrm{ha}^{-1}\right)$. However, the data showed non significant difference among different interactions.

\section{Nutrient use efficiency ( $\mathrm{kg} \mathrm{kg}^{-1}$ nutrient)}

The data on nutrient use efficiency of rice as influenced by irrigation and establishment methods are presented in the Table 7.

\section{Nitrogen use efficiency (NUE) (kg grain} $\left.\mathrm{kg}^{-1} \mathbf{N}\right)$

Among the different irrigation methods, the nitrogen use efficiency was non-significant. Among establishment methods, manual transplanting recorded higher NUE $(52.53 \mathrm{~kg}$ grain $\left.\mathrm{kg}^{-1} \mathrm{~N}\right)$ followed by mechanical transplanting $\left(51.71 \mathrm{~kg}_{\text {grain }} \mathrm{kg}^{-1} \mathrm{~N}\right)$ and were significantly higher as compared to rest of the methods (41.97 to $49.53 \mathrm{~kg}$ grain $\mathrm{kg}^{-1} \mathrm{~N}$ ). However, among interactions, alternate wetting and drying up to PI followed by flooding after PI with manual transplanting recorded significantly higher NUE $(57.45 \mathrm{~kg}$ grain $\mathrm{kg}^{-1} \mathrm{~N}$ ) which was closely followed by alternate wetting and drying up to PI followed by flooding after PI with mechanical transplanting (56.13 kg grain $\left.\mathrm{kg}^{-1} \mathrm{~N}\right)$ as compared to rest of the interactions (39.53 to $52.02 \mathrm{~kg}_{\text {grain }} \mathrm{kg}^{-1} \mathrm{~N}$ ). This may be due to the effective utilization of nitrogen through reduced losses in alternate wetting and drying method of irrigation and effective absorption of nutrients through well developed deep root systems in transplanted rice. Similar results were reported by Borkar et al., (2008).

Phosphorus (PUE) (kg grain $\mathrm{kg}^{-1} \mathrm{P}_{2} \mathrm{O}_{5}$ ) and Potassium use efficiency (KUE) (kg grain $\mathrm{kg}^{-1} \mathrm{~K}_{2} \mathrm{O}$ )

Among irrigation methods, continuous flooding recorded higher PUE and KUE

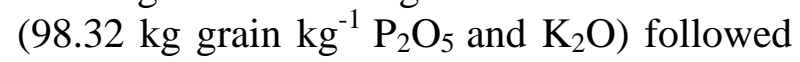
by alternate wetting and drying up to PI followed by flooding after PI $(96.99 \mathrm{~kg}$ grain

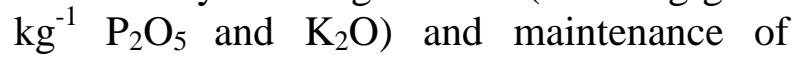
saturation up to PI followed by flooding after PI (96.56 kg grain $\mathrm{kg}^{-1} \mathrm{P}_{2} \mathrm{O}_{5}$ and $\mathrm{K}_{2} \mathrm{O}$ ). Manual transplanting among establishment methods recorded significantly higher PUE and KUE (105.05 kg grain $\mathrm{kg}^{-1} \mathrm{P}_{2} \mathrm{O}_{5}$ and $\mathrm{K}_{2} \mathrm{O}$ ) followed by mechanical transplanting (103.43 $\mathrm{kg}$ grain $\mathrm{kg}^{-1} \mathrm{P}_{2} \mathrm{O}_{5}$ and $\mathrm{K}_{2} \mathrm{O}$ ) as compared to rest of the methods (83.93 to $99.06 \mathrm{~kg}$ grain 
$\mathrm{kg}^{-1} \quad \mathrm{P}_{2} \mathrm{O}_{5}$ and $\mathrm{K}_{2} \mathrm{O}$ ). Interaction between alternate wetting and drying up to PI followed by flooding after PI and manual transplanting recorded significantly higher PUE and KUE (114.89 kg grain $\mathrm{kg}^{-1} \mathrm{P}_{2} \mathrm{O}_{5}$ and $\mathrm{K}_{2} \mathrm{O}$ ) which was closely followed by alternate wetting and drying up to PI followed by flooding after PI with mechanical transplanting $(112.26 \mathrm{~kg}$ grain $\mathrm{kg}^{-1} \mathrm{P}_{2} \mathrm{O}_{5}$ and $\mathrm{K}_{2} \mathrm{O}$ ) over rest of the interactions (81.86 to $104.05 \mathrm{~kg}$ grain $\mathrm{kg}^{-1}$ $\mathrm{P}_{2} \mathrm{O}_{5}$ and $\mathrm{K}_{2} \mathrm{O}$ ). Among establishment methods, manual transplanting and mechanical transplanting recorded higher NUE, PUE and KUE. The possible reason may be due to transplanting of young age seedlings where root injury is minimal and that helped in quick establishment after transplantation and hence efficient utilization of applied nutrients for its growth and development. Results are in confirmation with Sowmyalatha (2015).

\section{Economics}

The data on cost of cultivation, gross returns, net returns and $\mathrm{B}$ : $\mathrm{C}$ ratio of rice as influenced by irrigation and establishment methods and their interactions are presented in Table 8.

\section{Cost of cultivation $\left(\square \mathbf{h a}^{-1}\right)$}

Among irrigation methods, alternate wetting and drying up to PI followed by flooding after PI recorded lower cost of cultivation $(42,050$ $\square \mathrm{ha}^{-1}$ ) over rest of the methods (43,650 to 45,850 $\square \quad$ ha $\left.^{-1}\right)$. Among establishment methods, lower cost of cultivation $(40,390$ $\mathrm{ha}^{-1}$ ) was recorded in semi dry rice than other methods (42,590 to 47,365 $\square$ ha $^{-1}$ ). Among treatment combinations, alternate wetting and drying up to PI followed by flooding after PI with semi dry rice recorded lower total cost of cultivation $\left(38,590 \square \mathrm{ha}^{-1}\right)$ as compared to rest of the treatment combinations $(40,190$ to 49,365 $\square \mathrm{ha}^{-1}$ ). Lower cost of cultivation under alternate wetting and drying up to PI followed by flooding after PI may be due to the reduced irrigation costs while lower cost of cultivation in semi dry rice may be due to the reduced puddling, nursery raising and transplanting costs (Shantappa, 2014).

\section{Gross and net returns ( $\square \mathbf{h a}^{-1}$ )}

Continuous flooding recorded higher gross returns $\left(84,777 \square \mathrm{ha}^{-1}\right)$ than other methods (83,634 to $84,545 \square \mathrm{ha}^{-1}$ ) whereas, alternate wetting and drying up to PI followed by flooding after PI recorded higher net returns $\left(42,495 \square \mathrm{ha}^{-1}\right)$ than other methods $(38,927$ to 39,984 $\square$ ha $^{-1}$ ) among irrigation methods. Among establishment methods, mechanical transplanting recorded higher gross returns (90,680 $\left.\square \mathrm{ha}^{-1}\right)$ as compared to rest of the methods $\left(72,832\right.$ to $90,552 \square$ ha $\left.^{-1}\right)$ however, semi dry rice recorded higher net returns $\left(45,184 \square \mathrm{ha}^{-1}\right)$ as compared to rest of the methods $\left(30,242\right.$ to $44,615 \square$ ha $\left.^{-1}\right)$. However, lower gross and net returns were recorded in broadcasting of sprouted rice (72832 and $30242 \square$ ha $^{-1}$ ). Higher gross returns may be due to higher grain and straw yield whereas, higher net returns may be mainly due to lower cost of cultivation. Similar results were reported by Manjunatha et al., (2009b) and Jayadeva and Prabhakara Shetty (2008). Among treatment combinations, higher gross returns and net returns $(99,377$ and 55,112 $\square$ $\mathrm{ha}^{-1}$, respectively) were recorded in alternate wetting and drying up to PI followed by flooding after PI with mechanical transplanting over rest of the treatment combinations $(68,681$ to 99,068 and 26,291 to $53,503 \square$ ha $^{-1}$,respectively).

\section{B: C ratio}

Among irrigation methods, alternate wetting and drying up to PI followed by flooding after PI recorded higher $\mathrm{B}$ : $\mathrm{C}$ ratio (2.00) than other methods (1.86 to 1.92). However, among establishment methods, semi dry rice 
recorded higher $\mathrm{B}$ : $\mathrm{C}$ ratio (2.12) over other methods (1.71 to 1.97). Alternate wetting and drying up to PI followed by flooding after PI with mechanical transplanting among treatment combinations recorded higher B: C ratio (2.25) than rest of the treatments (1.67 to 2.18). Higher B: $C$ ratio may be due to higher net returns and lesser cost of cultivation. These results are in line with Jayadeva and Prabhakara Shetty (2008).

In conclusion the efficient water saving technology and method of establishment on nutrient uptake in rice has been evaluated. Among irrigation methods, alternate wetting and drying up to PI followed by flooding after PI recorded higher leaf area than other methods at 90 DAS and at harvest. In establishment methods, mechanical transplanting recorded significantly higher leaf area. However, at 90 DAS and at harvest, alternate wetting and drying up to PI followed by flooding after PI method of irrigation recorded significantly higher dry matter. However, at 60, 90 DAS and at harvest, mechanical transplanting among establishment methods recorded significantly higher dry matter over rest of the methods. Manual transplanting among rice establishment methods recorded significantly higher grain yield. Among rice establishment methods, mechanical transplanting recorded significantly higher total nitrogen uptake, total phosphorus uptake and total potassium uptake. However, manual transplanting recorded higher NUE, PUE and KUE. Among irrigation methods, alternate wetting and drying up to PI followed by flooding after PI recorded lower cost of cultivation, higher net returns and $\mathrm{B}$ : $\mathrm{C}$ ratio. Among treatment combinations, higher gross returns, net returns and B: C ratio was recorded in alternate wetting and drying up to PI followed by flooding after PI with mechanical transplanting.

\section{References}

Anjani, K., Dasgupta, Pragnakumar and Rakesh. 2014, Emerging opportunities and challenges in rice production. Popular Kheti., 2(2): 6-11.

Anonymous, 2017, Area, production and productivity of rice in India, Ministry of Agriculture and Farmers Welfare, Govt. of India. pp. 1-2.

Borell, A. K., Garside, A. and Fukai, S., 1997, Improving efficiency of water use for irrigated rice in a semi-arid tropical environment. Field Crops Res., 52: 231-248.

Borkar, L. S., Khawale, V. S., Raut, B., Patil, T. S. and Kolte, H. S., 2008, Studies on spacing and nitrogen management under system of rice intensification (SRI). J. Soils Crops, 18(2): 438-441.

Bouman, B. A. M. and Toung, T. P., 2001, Field water management to save water and increase productivity in irrigated low land rice. Agric. Water Manag., 49: 11-30.

Bouman, B. A. M., Peng, S., Castaneda, A. R. and Visperas, R. M., 2005, Yield and water use of irrigated tropical aerobic rice systems. Agric. Water Manag., 74: 87-105.

Chandrapala, A. G., Yakadri, M., Mahender, K. R. and Bhupal, R. G., 2010, Productivity and economics of rice (Oryza sativa L.)-maize (Zea mays L.) as influenced by methods of crop establishment, $\mathrm{Zn}$ and $\mathrm{S}$ application in rice. Indian J. Agron., 55(3): 171-176.

Christine, K., Klaus, D., Xunhua, Z., Zhang, X., Shan, L., Hongbin, T. and Burkhard, S., 2007, Fluxes of methane and nitrous oxide in water-saving rice production in north China. Nutr. Cycl. Agroecosyst., 77: 293-304.

Dass, A. and Chandra, S., 2012, Effect of different components of SRI on yield, quality, nutrient accumulation and 
economics of rice (Oryza sativa) in tarai belt of northern India. Indian. $J$. Agron., 57(3): 250-254.

Dhawan, V., 2017, Water and Agriculture in India. Presented in: Glob. Forum Food Agric., pp. 17-24.

Dubey, R. S. and Pessarakli, M., 2001, Physiological mechanisms of nitrogen absorption and assimilation in plants under stressful conditions. In: Passarakli M (Ed). Handbook of Plant and Crop Physiology ( $2^{\text {nd }}$ Edn), Marcel Dekker Inc, New York, pp 636-655.

Farooq, M., Kadambot, H. M., Siddique, Rehman, H., Aziz, T., Dong Jin Lee and Wahid, 2011, Rice direct seeding: Experience challenges and opportunities. Soil Tillage Res., 111: 87-98.

Gopi, R., Ramesh, S., Pandian, B. J., Chandrasekaran, B. and Sampathkumar, T., 2006, Evaluation of crop establishments and split application of $\mathrm{N}$ and $\mathrm{K}$ on growth, yield attributes, yield and economics of hybrid rice Co RH2. Asian J. Plant Sci., 5(6): 10221026.

Hugar, A. Y., Chandrappa, H., Jayadeva, H. M., Salish, A. and Mallikarjun, G. B., 2009, Comparative performance of different rice establishment methods in Bhadra command area. Karnataka J. Agric. Sci., 22(5): 992-994.

Jat, A. L., Srivastava, V. K. and Rajesh, K. S., 2015, Effect of crop-establishment methods and integrated nitrogen management on productivity of hybrid rice (Oryza sativa)-wheat (Triticum aestivum) cropping system. Indian $J$. Agron., 60(3): 341-346.

Jayadeva, H. M. and Prabhakara Shetty, T. K., 2008, Influence of crop establishment techniques and sources of nutrients on productivity, energetic and economics of rice. Oryza., 45(2): 165168.
Lampayan, R. M., Rejesus, R. M., Singleton, G. R. and Bouman, B. A. M., 2015, Adoption and economics of alternate wetting and drying water management for irrigated lowland rice. Field Crops Res., 170: 95-108.

Malik, R. K., Kamboj, B. R., Jat, M. L., Sidhu, H. S., Bana, A., Singh, V., Saharawat, Y. S., Pundir, A., Sahnawaz, R. D., Anuradha, T. and Kumaran, N., 2019, No-till and unpuddled mechanical transplanting of rice-operational manual. Gates Open Res, 3.

Manjunatha, B. N., Basavarajappa, R. and Pujari, B. T., 2009b, Effect of age of seedlings on growth, yield and water requirement by different system of rice intensification. Karnataka J. of Agric. Sci., 23(2): 231-234.

Nguyen, H. T., Fischer, K. S. and Fukai, S., 2009, Physiological responses to various water saving systems in rice. Field Crops Res., 112: 189-198.

Rani, S. and Sukumari, P., 2013, Root growth, nutrient uptake and yield of medicinal rice njavara under different establishment techniques and nutrient sources. Am. J. Plant Sci., 4: 15681573.

Satyanarayana, A. and Babu, K. S., 2004, A revolutionary method of rice cultivation. In: Manual on system of rice intensification (SRI), Acharya N. G. Ranga Agric. Univ., pp. 6.

Shantappa, D., 2014, Studies on establishment techniques, irrigation water levels and weed management practices on productivity and emission of green house gasses (Ghgs) in rice (Oryza sativa L.). Ph.D. Thesis, Univ. Agric. Sci., Raichur.

Singh, Y. P. Singh, G. Singh, S. P. Kumar, A. Sharma, G., Singh, M. K., Mortin, M. and Johnson, D. E., 2006, Effect of weed management and crop establishment methods on weed 
dynamics and grain yield of rice. Indian J. Weed Sci., 38(1-2): 20-24.

Somasundaram, K., Annadurai, K., Manoharan, M. L., Kavimani, R. and Vijayalakshmi., 2000, Handbook on rice production technology. Golden net printers, Trichy, pp. 122.

Sowmyalatha, B. S., 2015, Standardization of agro-techniques for mechanized system of rice (Oryza sativa L.) intensification. Ph.D Thesis., Univ. Agric. Sci., Bengaluru.

Subramaniam, G., Kumar, M. R., Humayaun, P., Sriniva, V., Kumari, R. B., Vijayabharathi, R., Singh, A., Surekha, K., Padmavathi, C. H., Somashekar, N., Rao, R. P., Latha, P. C., Rao, S. L. V., Babu, V. R., Viraktamath, B. C., Goud, V. V., Gujja, B. and Om, R., 2013, Assessment of different methods of rice cultivation affecting growth parameters, soil chemical, biological and microbiological properties, water saving and grain yield in rice-rice system. Paddy Water Environ., pp. 254263.

Taiz, L. and Zeiger, E., 2006, Plant Physiology (4th Edn), Sinauer Associates, Massachusetts, pp. 690.

Yadav, A. S., Jaidev, Ram, H. and Upadhyay, M. K., 2010, Effect of nitrogen levels and plant geometry on growth, yield and root characteristics of hybrid rice (Oryza sativa). Crop Res., 40(3): 16-19. Yadav, D. B., Yadav, A., and Punia, S. S., 2009, Evaluation of bispyribac-sodium for weed control in transplanted rice. Indian J. Weed Sci., 41(1-2): 23-27.

\section{How to cite this article:}

Theerthana, T., P. S. Fathima, G. R. Denesh, S. S. Prakash and Asha, N. N. 2020. Influence of Irrigation Management Practices and Different Establishment Methods on Nutrient Use Efficiency of Rice. Int.J.Curr.Microbiol.App.Sci. 9(11): 3213-3233. doi: https://doi.org/10.20546/ijcmas.2020.911.387 